\title{
The Corporate Securities Act' Recent Cases and Amendments
}

\section{Procedure}

CINCE 1917, when California discarded the Investment Companies $\mathrm{Act}^{2}$ in favor of the Corporate Securities Act, a number of cases have arisen testing and interpreting the new method of licensing and regulation. The decisions, together with the several important changes made by the legislature, will be considered in order to ascertain the present status of the law, and the effect of the changes made. With each addition to the Act there is the same conflict. How far can the state go in precautions against corporate juggling and abuse and not unreasonably hamper the pursuit of legitimate business?

In order to obtain a clcar idea of the increased burden put upon the process of incorporating and issuing securities under the Act and to counteract erroneous impressions as to the methods followed by the Corporation Department, a brief outline of the usual proceedings to procure a permit or license is first given.

1. An application is filed for a permit to issue stocks or bonds. Section 3 of the Act contains the requirements of this application. However, for new applicants, it is advisable first to procure a copy of the suggestions, and the forms and blanks prepared by the department. A new set of rules and forms has recently been issued.

2. The second step usually consists of informal talks and conferences between the applicant and the department deputies. Many a valuable suggestion may thus be obtained to help the inexperienced lawyer or promoter to get his corporation successfully launched.

3. In many cases the influence of the deputies will check a tendency toward over-enthusiasm on the part of the promoter, and results in amendments to the application decreasing the amounts of stocks to be issued, changing the type of securities, increasing the assets, or altering the contemplated plans of building or expansion.

4. The application is then checked as a whole by the deputy in charge of it and sent to the auditing department.

5. If everything proves satisfactory in the auditing and investigation, it is sent to the chief deputy, who is the assistant to the Com-

1 Cal. Stats. 1917, ch. $: 32$; Cal. Stats. 1919, ch. 148; Cal. Stats. 1921, ch. 597 and 658; Cal. Stats. 1923, ch. 50; Cal. Stats. 1925, ch. 447.

2 Cal. Stats. 1913, ch. 353; Cal. Stats. 1915, ch. 609. 
missioner. He is the one man who passes on all of the applications from each of the three offices of the department: San Francisco, Los Angeles and Sacramento. Thus all applications, though presented at different places, are given uniform and equal treatment. He checks the conditions imposed by the first deputy and may change them or add others.

6. Finally the permit, with conditions attached, is issued. The general purpose of these conditions is to insure a certain amount of tangible assets to be acquired and retained by the company. Thus the Commissioner often requires reports as to money and other assets received, and a showing that the proceeds from the sale of the securities have been used in accordance with the permit. In many cases, too, when stock is issued for services or property, the permit requires the same to be held in escrow pending further orders of the Commissioner. Such stock is ordinarily only released after the company's business is established. ${ }^{3}$

7. Where a broker or agent applies for a certificate to sell securities, the procedure is much simpler. In the usual case the only investigation that is required is a few inquiries by phone or a personal call from the references given in the application. A broker's certificate must be obtained yearly ${ }^{4}$ so the Commissioner has a closer check on these men who are itinerant, and who are dealing with varied types of securities. It is significant that the greater number of breaches of the Act prosecuted are against men of this type rather than against corporation promoters.

If the application for a permit or license is not satisfactory, sections 4 and 6 declare, ". . . . he [the Commissioner] shall deny the application and refuse such permit and notify the applicant in writing of his decision." This is ordinarily done in conference, where the reasons are gone over with the applicant and suggestions made as to changes which will make it satisfactory. If such changes are not made and the applicant still feels that the permit is being wrongfully refused, he has the right of review by a court. Previous to the 1925 amendment this was the Superior Court of Sacramento County, but this statute eliminated the restriction to this one tribunal and leaves the only procedure that specified in sections $1067-1077$, inclusive, of

${ }^{3}$ It is estimated by the Corporation Department that $95 \%$ of the corporations given a permit to issue stocks and licensed to incorporate have failed or gone out of business within the period of five years.

"Section 5 of the Act reads, "Every such certificate shall expire on the thirty-first day of December next after its issuance unless sooner revoked." People v. Eiseman (1923) 61 Cal. App. 783, 215 Pac. 1032. 
the Code of Civil Procedure, as to writs of review, and will further facilitate a review of the case. The determination on review is limited to the single question, Has there been an abuse of discretion by the Commissioner? Recent cases have indicated that the courts incline to uphold the Commissioner.

Up to January 1, 1923, if any complaint was lodged with the Corporation Department regarding breaches of the Act, and investigation warranted revocation of a permit or broker's license, the parties concerned were called and after an informal hearing, the permit or license was revoked. The case of Abrams $v$. Daugherty ${ }^{5}$ caused a material change to be made in this procedure. Here a broker's license was temporarily suspended at such an informal hearing, of which the broker was only given notice to come and show cause why his license should not be revoked. The court annulled the Commissioner's orders and held that the right to carry on the profession of stock broker was a valuable property right, and as such was constitutionally entitled to protection. To meet this requirement the Commissioner must give notice as to the time, place, and nature of the hearing, and allow the parties concerned time to prepare a defense. This is in accord with decisions as to medical and dental examiners, ${ }^{6}$ milk inspectors, and the Real Estate Board; ; but it is to be regretted if, as a reseult of this case, the Commissioner must, in the ordinary cases of applications and changes in applications, also discard his present satisfactory procedure for formal hearings entailing reporters, sworn witnesses, and all that goes with court procedure. The refusal of an application or permit is as much a deprivation of a valuable property right as the revocation, but up to the present time the requirement for the formal hearing has been restricted entirely to revocations. Any further extension would result in a longer time for the consideration of applications, increased technicality, and a corresponding dissatisfaction by those who deal with the department. The right of review is sufficient constitutional protection to those who feel that the Commissioner has over-stepped his discretionary limits.

5 (1922) 60 Cal. App. 297, 212 Pac. 942. The constitutionality of the new procedure adopted since this case has been upheld in Leach v. Daugherty, infra, n. 17.

6 Suckow y. Alderson (1920) 182 Cal. 247, 187 Pac. 965; Hewitt v. Board of Medical Examiners (1906) $148 \mathrm{Cal}$. 590, $84 \mathrm{Pac} .39$, $113 \mathrm{Am}$. St. Rep. 315, 3 L. R. A. (N. S.) 896; Dyment v. Board of Medical Examiners (1922) 57 Cal. App. 260, 207 Pac. 409; People use of State Board of Health v. McCoy (1888) 125 III. 289, 17 N. E. 786; State v. Shultz (1892) 11 Mont. 429, 28 Pac. 643.

Brecheen v. Riley (1921) 187 Cal. 121, 200 Pac. 1042; Levy Dairy Co. v. Wilson (1917) 179 App. Div. 416, 166 N.' Y. Supp. 211. 
There has been some criticism of the Act centered particularly around the delay it causes in the placing of securities on the market. It may be said, however, that the reorganization of the department, ${ }^{8}$ adopting the plan of procedure above outlined, and a substantial increase in the staff have resulted in a reduction of the time for consideration of applications from five weeks to an average of five days for each application at the present time. This compares very favorably with any state which has an Act of the type of the California Act, requiring both applieations and licensing. ${ }^{\circ}$

\section{SCOPE OF THE COMMISSIONER's Discretion}

The discretionary powers granted to the Commissioner of Corporations in California, are found in a very few sections of the Act and Civil Code. Section 4 of the Act reads,

"Upon the filing of such application, it shall be the duty of the Commissioner to examine it . . ., and he may, if he deems it advisable, make or have made a detailed examination, audit and investigation of the applicant and its affairs. If he finds that the proposed plan of business ... is not unfair, unjust, or inequitable, that it intends to fairly and honestly transact its business, and that the securities it proposes to issue and methods to be used by it . . are not such as, in his opinion, will work a fraud on the purchaser thereof, the Commissioner shall issue to the applicant a permit authorizing it to issue and dispose of securities . . . in this state, in such amounts, and for such considerations, and upon such terms and conditions as the Commissioner may in such permit provide." (Italics added.)

Here the standard is set for the Commissioner's determination of applications, and unless an abuse of his discretion is shown in deciding that the plan is not fair, just, or equitable, or the means used are fraudulent, the courts will uphold the decision of the Commissioner. ${ }^{10}$ But to what may the Commissioner look to find the facts upon which to base this determination? Is he bound by the statements in the application or can he go beyond these and disregard them if neces-

8 The department is divided into 3 working divisions: legal, accounting, and engineering. There are three offices of the department, and the Commissioner and his chief deputy travel from one office to another. The general headquarters is in Sacramento.

O For a good discussion of the various types of Blue-Sky laws, see 24 Columbia Law Review, 79.

10 People v. Boggess, infra, n. 77 ; Doble Steam Motors Corp. v. Daugherty, infra, n. 11; Domenigoni y. Imperial Livestock and Mortg. Co. (1922) 189 Cal. 467, 209 Pac. 36; Brecheen v. Riley, supra, n. 7; Cox v. Daugherty (1923) 64 Cal. App. 621, 222 Pac. 178; People v. McCalla, infra, n. 35. 
sary? Doble Steam Motors Corporation v. Daugherty ${ }^{11}$ met this issue squarely.

The corporation, in that case, having 100,000 shares of stock outstanding, had applied to the Commissioner for a permit to issue 37,000 additional shares. The application met all the statutory requirements as to purpose and facts and included a statement of a surrender of shares of an ostensible value of $\$ 3,000,000$ which was to cover the new issue, and appended contracts on which the corporation had placed a value. The Commissioner, however, looked beyond these facts and into the departmental records for previous applications to determine the true value of the shares; and found the actual condition of the business to be different from the impression given by the facts in the application. Outside investigation showed that an advance sale of the proposed issue had been made without a permit, by brokers then insolvent; and that the issuance of the permit would result in but a small portion of the sale price actually going to the issuing company. Further, the contracts for the purchase of patent rights were found of doubtful value. The permit was refused and the company sued out a writ of mandate to compel the Commissioner to issue a permit on the basis of the facts stated in the application. The contention was, that the facts in the application, if taken as true, justified the issuance of a permit; that if the Commissioner did not assume the truth of them, he must grant a hearing and give the applicant an opportunity to prove the truth of its statements. The Supreme Court upheld the Commissioner and refused to grant the writ, saying that the Act vested the Commissioner with a discretion to grant or deny a permit whenever from the face of the appiication there is a statement of facts which, even though taken to be true, give rise to a reasonable doubt as to the fairness and justness of the proposed plans and methods. An applicant's statement of value of shares of stock outstanding, or the worth of proposed contracts for the purchase of patent rights are certainly of a class of facts open to a difference in opinion ${ }^{12}$ and it is the Commissioner $s$ duty in deciding on the fairness or equity of the plan, to go as tar as he can to determine the true value of these assets.

11 (Dec. 22, 1924) 69 Cal. Dec. 1, 232 Pac. 140. This reversed the decision of the District Court of Appeal. Doble Steam Motors Corp. v. Daugherty (1924) 44 Cal. App. Dec. 603 .

12 It may well be contended that statements as to the cost of property, 'salaries of employees and such facts of which the only reason for outside investigation is a belief that the applicant was untruthful, would not be of a class that the Commissioner could disregard without a hearing. 
The result of the case was a surprise to many corporation lawyers of the state who had theretofore believed that the Commissioner was strictly limited in the exercise of his discretion, being bound to assume the truth of all the statements in the verified application, or in case of doubt to have a hearing before refusal. The decision is well in accord with decisions as to other administrative bodies in this state, ${ }^{13}$ and cases in other jurisdictions. ${ }^{14}$ In an analogous case under the Board of State Harbor Commissioners, the general rule of constitutional law applying to these administrative bodies was stated,

"Where the Boards are given discretion, courts will not interfere in the absence of grave reasons showing fraud, corruption, improper motives or influence, plain disregard of duties, gross abuse of power, or violation of law in their determinations." "10

The basis of efficient regulation by administrative bodies is the power of discretionary action placed in the executives at the head. The courts should uphold this to the fullest extent possible within constitutional limits if they are to further the effectiveness of such bodies as the Corporation Department.

The 1925 amendment to the Corporate Securities Act clarifies the latter part of section 4, stating specifically certain powers of the Commissioner which theretofore may or may not have been included under, ". . . such other conditions as he may deem reasonable or necessary or advisable..." It now reads in addition,

“. . . may impose conditions requiring the deposit in escrow of securities, the impoundment of the proceeds from the sale thereof, limiting the expense in connection with the sale thereof ..."

This will have the immediate effect of warding off certain contemplated litigation which was to test the Commissioner's power in safeguarding the proceeds from the sale of securities.

Section 6 states further discretionary powers, giving the Commissioner a right to make an independent investigation where he deems it necessary to determine facts not stated in the application.

13 Brecheen v. Riley, supra, n. 7; Suckow v. Alderson, supra, n. 6; Ex parte Whitley (1904) 144 Cal. 167, 77 Pac. 879; Frasher v. Rader (1899) 124 Cal. 132, 56 Pac. 797; Spring Valley Water Works v. San Francisco (1890) 82 Cal. 286, 22 Pac. 910, 16 Am. St. Rep. 116, 6 L. R. A. 756.

14 German Alliance Ins. Co. v. Lewis (1914) 233 U. S. 389, 58 L. Ed. 1011, 34 Sup. Ct. Rep. 612; Dailey v. New Haven (1891) 60 Conn. 314, 22 Ati. 945, 14 L. R. A. 69; Wiley v. Alleghany County Commis. (1879) 51 Md. 401 ; Brogger v. C. St. P., M. \& O. Ry. Co. (1917) 137 Minn. 338, 163 N. W. 662. Also see 36 Harvard Law Review, 405 and 583, 589. 754.

15 Union Transportation Co. v. Bassett (1897) $118 \mathrm{Cal}$. 604, 610, 50 Pac. 
It also provides for suspension and revocation of certificates of brokers where he finds that the holders thereof are of bad business repute or have violated any provision of the Act, or are about to engage in any fraudulent transaction. This handy weapon of the Commissioner will be more extensively treated of in the consideration of penalties. Section 6 has also been slightly altered by the 1925 amendment, but only to add a few more situations in which the Commissioner may exercise his discretion. Specification of actual instances is always advisable as it aroids test cases to determine the scope of general powers originally granted.

Some question was raised in Leach $v$. Daugherty ${ }^{16}$ as to the constitutionality of section 6 , on the ground that it was an unauthorized delegation of legislative power to the Commissioner in allowing him to decide what shall constitute "good business repute," there being no standards for his determination set down in the Act.

The court again upheld the Commissioner's discretion, basing its decision upon

"the well settled principle of law . . . that by legislative act a commission or board may be enpowered to ascertain the existence of facts, upon the finding of which may depend the right to continue in the practice of a profession or a regulated business."

Another power, granted in section 7 of the Act, but seldom seriously considered by the Corporation Department or the public, is that allowing the Commissioner to prevent the circulation of advertising matter which he believes is false or misleading to the reader. It is difficult to ascertain the existence of such matter unless the public which is regularly besieged with all sorts of pamphlets and prospectuses will co-operate by reporting the issuance of these, to the Commissioner. The two most recent frauds investigated by the Corporation Department, and given wide newspaper publicity, were preceded by a circulation of literature within the provisions of section 7 , but this was not discovered until the alleged frauds had been committed. ${ }^{18}$ The federal government is paying much more attention to this means of preventing fraudulent schemes and has recently con-

16 (June 1, 1925) 47 Cal. App. Dec. 311, 238 Pac. 160.

17 Leach v. Daugherty, 47 Cal. App. Dec. 311, 314. This point was originally settled in the leading American case sustaining the validity of BlueSky laws, Hall v. Geiger-Jones Co. (1916) 242 U. S. 539, 61 L. Ed. 480, 37 Sup. Ct. Rep. 217. See cases cited, supra, n. 13.

18 One case, in regard to the Carson Valley Mining Co. is being prosecuted at the present time. The other, involving the collapse of the brokerage concern of Carey \& Co. involves a very heavy loss to the persons deating with it, for the head of the concern, after his fraudulent campaign, absconded. 
victed several persons for circulating such literature in violation of the postal laws. ${ }^{19}$

In investigations, and consideration of applications, the Commissioner amasses a great amount of information, which by section 10 he may withhold or make public as he believes the interests of the corporation or the public demand. This riglit is found in nearly all of the Blue-Sky laws. ${ }^{20}$

The scope of the discretion lying in the Commissioner is large but this does not mean that he may be arbitrary in the exercise of it. Nor does it mean, as has been contended by critics of this part of the Act, that he has the right under the guise of protecting the purchaser, to alter or reduce amounts of stock which the applicant desires to issue, or change the type of stock, as from common to preferred, as a condition of the permit, without a hearing or good and sufficient rcasons therefor. The Act provides that conditions may be attached to the permit for the purpose of protecting the subscribers and stockholders, but the method used in determining and applying these is that outlined previously, and not an arbitrary decree at the whim of the Commissioner.

Among the most important of those discretionary questions it devolves upon the Commissioner to settle, is the permitting of corporations to create debts beyond their subscribed capital stock, or make dividends otherwise than from surplus profits. The restriction, as found in Civil Code, section 309, was early held to be entirely on the directors of the corporation. But no matter how much in excess of the subscribed capital stock, a creation of debts is lawful if the Commissioner will give his consent. For instance, Mr. Carnahan, the first Commissioner in California, received an application from the Huntington Land and Improvement Company of Los Angeles for the issuance of bonds to the amount of $\$ 10,000,000$. Though at this time the subscribed capital stock of the applicant was only $\$ 100,000$, the company was very wealthy and had more than enough tangible assets to cover the proposed indebtedness. The permit was issued under section 309, the Commissioner stating at the time, that any restrictions found in the section were entirely on the corporation

${ }^{10}$ Outstanding among recent convictions is that of Cook, the polar explorer who is now serving a term in federal prison for leading a fraudulent campaign to enlist subscribers for fictitious oil wells in Oklahoma.

20 Minn. Gen. Laws, 1925, ch. 192, n. 1, § 20; Mo. Laws, 1923, p. 200, Mo. Laws, 1925, p. 218, § 17; Utah, Gen. Laws, 1925, ch. 87, § 5; Wash. Laws, 1923, ch. $66, \S 15$. For others, see Reed and Washburn, Blue-Sky Law Service, division $\mathrm{V}$. 
directors, and where he deemed the proposition fair and equitable it was his duty to issue the permit.

The constitutionality of this section was recently considered in the two cases of Dominguez Land Corporation v. Daugherty. ${ }^{21}$ This time the question involved the discretion of the Commissioner to issue a permit "to make dividends except from the surplus profits arising from the business thereof, or to divide the capital stock."

By advice of the Attorney-General, the Commissioner had refused to assume jurisdiction over applications of the plaintiff company to distribute surplus money and property created by the reduction of its capital stock from $\$ 2,000,000$ to $\$ 1,000,000$; 'or from money collected from several assessments. The contention of the Commissioner was that Article XII, section 11 of the constitution, by its implied meaning, made Civil Code section 309 unconstitutional. The only portion of the constitutional section which is pertinent reads,

"No corporation shall issue stocks or bonds, except for money paid, labor done, or property actually received, and all fictitious increase of stock or indebtedness shall be void."22

This is the common provision of state constitutions to prevent the watering of stock, ${ }^{23}$ but in no state has this been held to prevent a distribution of surplus profits or capital as long as there remains a sufficient amount to cover the stocks and bonds outstanding plus other indebtedness. ${ }^{24}$ There is the usual exception however where there is fraud or bad faith in the transaction. ${ }^{25}$ In fact, California has been rather liberal in allowing stock to be issued for property of a value not actually equivalent to the par value of the stock; and neither at the instance of stockholders nor creditors have the transactions been held within these constitutional sections where the corporation is left in a safe financial condition, the proceedings being in good faith. ${ }^{26}$

21 (July 29, 1925) 70 Cal. Dec. 91, Pac ; (July 29, 1925) 70 Cal. Dec. $102, \ldots . . .$. Pac. Art. XII, $\S 11$.

285 Fletcher, Cyc. Corporations, § 3525.

24 Memphis \& L. R. R. Co. v. Dow (1887) 120 U. S. 287, 30 L. Ed. 595, 7 Sup. Ct. Rep. 482 ; Peoria \& S. R. Co. v. Thompson (1882) 103 Ill. 187; Mathis v. Pridham (1892) 1 Tex. Civ. App. 58, 20 S. W. 1015; 5 Fletcher, Cyc. Corporations, $\$ 3525$.

25 James v. Steifer Mining Co. (1918) 35 Cal. App. 778, 171 Pac. 117.

${ }^{26}$ McKee v. Title Ins. Co. (1911) 159 Cal. 206,113 Pac. 140; O'Dea v. Hollywood Cemetery Assn. (1908) 154 Cal. 53, 97 Pac. 10; Kellerman v. Maier (1897) 116 Cal. 416, 48 Pac. 377; Stein v. Howard (1884) 65 Cal. 616, 4 Pac. 662; Turner v. Fidelity Loan Concern (1905) 2 Cal. App. 122, 83 Pac. 62. 
The court in both the Dominguez cases supported the company and ordered the Commissioner to take jurisdiction of the application. It declared that there was no constitutional limitation upon the distribution of either surplus capital or money from assessments as long as the corporation was solvent and the disbursement would leave it in a condition whereby there were more assets than debts outstanding; and that the legislature could prescribe and regulate the terms and conditions upon which this could be done. The legislature saw fit to prescribe the means of determining these conditions in section 309, which delegated the duty to the Commissioner of Corporations. In his determinations, he is to look to those standards found in the Corporate Securities Act, "Whether the distribution will leave the corporation in a safe financial condition."

Anticipating the decisions in these cases, and in order to provide a sufficiently protective procedure to creditors in situations of this kind where the corporation desires to distribute its capital stock, or dividends other than surplus profits, the 1925 legislature passed section $309 \mathrm{x} / 2$.

The result of the Dominguez cases is to be commended; and any code section which clarifies the method of procedure to be used is to be equally commended, but if the legislature throws discretionary duties properly belonging to an administrative board into the formal procedure of a trial court, there is certainly cause for criticism.

The point must be emphasized that no matter how many the virtues of a statute on paper, the practical workings and the effect of the act have to be anticipated if the ultimate purpose in view is to be realized. Many statutes have laudable aims, but whether they are the most practical means under the circumstances to accomplish these aims may ofttimes be doubted. The Blue-Sky law has a laudable aim, but it must be remembered that in almost every section it encounters a conflict between the freedom of legitimate business and the prevention of frauds; and that the legitimate business houses are by far in the majority. They bitterly oppose each step that adds more formality and technicality to proceedings if this can possibly be avoided in accomplishing the result. Their co-operation and help is essential for the success of the Corporate Securities Act; and it is so important that if by amendments to the Code, or to the Act itself, widespread complaint and dissension is caused, the result will be the repeal of the Act as a whole. ${ }^{27}$ Civil Code section $309 \mathrm{y} / 2$ is a step in this direction.

27 Hall v. Geiger-Jones Co., supra, n. 17; Plymouth Coal Co. v. Penn. (1913) 232 U. S. 531, 58 L. Ed. 713, 34 Sup. Ct. Rep. 359. 
The Commissioner is given power, and by the Dominguez cases is required, to take jurisdiction over an application to distribute dividends, capital stock or property other than dividends arising from surplus profits. Section $309 \mathrm{x} / 2$ provides for the form and the requirements of the application, and for its publication by the Commissioner. The last is an entirely new procedure. If no objection is filed within two weeks after publication, the Commissioner is to hear and determine the application. This is in accord with discretionary powers already granted him. But on the other hand, if an objection is filed, then the determination, which involves the same questions and for which the same standards are prescribed in the Act for the Commissioner to follow, is taken away from the Commissioner and given to the Superior Court. The corporation must now bring a writ of mandate and go to all the expense, delay, and trouble of a court action. Parties must be served, evidence procured, and pleadings made. Finally the Commissioner is to issue a permit, if one is granted, according to the order of the court.

By virtue of what is the judge of the Superior Court more qualified to determine this question than the Commissioner whose regular duty it is to settle the very same problem, and who has the staff and materials at his disposal? Does the additional protection to creditors by a formal court procedure outweigh the disadvantages of expense, time, and technicality, when there is always a right of appeal from the Commissioner's orders if there has been an abuse cf discretion? Is it logical to say that the Commissioner can decide whether there are enough tangible assets on hand to protect creditors and stockholders if no one of them objects to the application, but that it requires the Superior Court to decide the identical question if one of the creditors or stockholders does happen to object?

\section{Business Trusts ${ }^{28}$}

The status of the hybrid business trust in California has been determined by a number of cases, all of which center around interpretations of the various definitions found in the Act. ${ }^{29}$ The question is raised, are "trust certificates", "units", "interests in profits",

28 For an excellent discussion of the place of the business trust under the Blue-Sky laws, and a collection of the authorities on the subject, see Leland S. Duxbury, Business Trusts and Blue-Sky Laws, 8 Minnesota Law Review, 465.

There is no question now but that the business trust comes within the provisions of these laws. The leading case is People v. Clum (1921) 213 Mich. 651, 182 N. W. 136. Also see Home Lumber Co. v. Hopkins (1920) 107 Kans. 153, 190 Pac. 601.

20 Corporate Securities Act, $\$ 2$. 
or "percentages in land" covered by the word "securities" in the Act so as to give the Commissioner authority to regulate the issuance of these certificates or interests? Or, can the organization issuing rights or interests of this kind be brought under "company", "trust", or "partnership" as defined in the Act?

In re Girard ${ }^{30}$ held the Corporate Securities Act applicable to the business trust, and is the leading California case on the subject. Here four men formed a common-law trust and issued "unit shares", or proportional interests in the business to themselves, whereupon they resold them to the public without a permit. The court, upholding their conviction, held that such an organization was within the definition of "company", and also was specifically covered by section 2 , parts 4 and 5 of the Act which says,

"The word trust... includes all voluntary trusts ... created by an instrument in writing other than a will or judicial writ . . . to carry on any business or secure the payment or repayment of money."

Practically every jurisdiction with a Blue-Sky law is in accord with this holding, ${ }^{31}$ but several states ${ }^{32}$ have experienced more difficulty due to an absence of such a definition of "trust" as is found in the California Act. In such jurisdictions the words "company", "association", or "person". are extended to cover the situation.

The Girard case was followed the next year by Agnew v. Daugherty. ${ }^{33}$ This involved the conveyance of a lease and option of mining property to a trustee. The transferor then proceeded to create 3,000 "interests" in the property, its assets and profits, and sold these with the avowed purpose of improving the mine. The court found these "interests" analogous to the "unit shares" in the previous case, within the definition of "securities" in the Act, and declared a sale of them without a permit to be illegal.

The next case, In re Lamb, ${ }^{34}$ was the first limitation upon the power of the Commissioner over this type of organization. Here a title company held the legal title to certain oil lands and agreed to transfer this to Lamb or his nominees upon his completion of the

30 (1921) 186 Cal. 718, 200 Pac. 593.

31 State v. Cosgrove (1922) 36 Idaho, 278, 210 Pac. 393; Kinross v. Cooper (1922) 224 Ill. App. 111; Wagner v. Kelso (1923) 195 Iowa, 959, 193 N. W. 1; Weisendanger v. Lind (1923) 114 Kans. 523, 220 Pac. 263; King v. Commonwealth (1922) $197 \mathrm{Ky}$. 128, $246 \mathrm{~S}$. W. 162; State v. Summerland (1921) 150 Minn. 266, 185 N. W. 255; Schmidt v. Stortz (1922) 208 Mo. App. 439, 236 S. W. 694; Groby v. State (1924) 109 Ohio St. 543, 143 N. E. 126.

32 Home Lumber Co. v. Hopkins, supra, n. 28; Bryant v. Shaw (1920) 190 App. Div. 578, 184 N. Y. Supp. 315.

38 (1922) 189 Cal. 446, 209 Pac. 34.

34 (1923) 61 Cal. App. 321, 215 Pac. 109. 
drilling of certain wells. Lamb sold his equitable interest to eight different parties, reserving only an interest in the profits; and was arrested for selling securities of a "trustee" or "association" without a permit. The court distinguished the two previous cases, holding that, as Lamb was not a trustee of land, and there was no other res for him to hold in a trust capacity, it was not a trust. Nor was he selling the securities of any association, for in each instance the interests sold were his own.

This seemed to provide an opportunity to evade the Act by the sale of equitable interests in property. If the court had felt that this method of sale was one adopted solely to evade the law, it might have held that the title company was a trustee holding the legal title to the property. Then the various "interests" in the right to profits and to get the legal title at a later date were created and sold by Lamb, the vendees being the "cestuis", on the basis of the Agnew and Girard cases.

Whatever liberal tendencies in interpretation may have been shown by the court here, they were discarded in People v. McCalla. ${ }^{35}$ It is this decision that more truly represents the present majority riewpoint in the United States..$^{36}$ D Company, owning land, divided it into 4,000 parts and created a trust with itself as trustee. Then, by grant deed, it sold these 4,000 th parts to various parties, subject to the condition that the $\mathrm{D}$ Company (trustee) manage the land, pay all expenses, take out $5 \%$ of the gross profits in return for such work, and distribute the remainder of the proceeds proportionally among the owners. The trustees were made removable by vote; and the profit certificates which represented the right to the proceeds were assignable, so that all of the desired features of the corporation were acquired. The court quashed the scheme, deciding that this constituted the issuance and sale of "securities" without a permit, basing its decision upon section $6(\mathrm{c})$ of the Act,

"any instrument issued or offered to the public by any company, evidencing or representing any right to share in profits or earnings . . . of any business carried on for profit."

Thus another avenue for the promotion of risky ventures has been closed. In this case the outward evidence of actual ownership of the property was in the holders of the certificates but this failed to deter the court from holding that as to meeting the requirements

35 (1923) 63 Cal. App. 783, 220 Pac. 436.

so See cases cited, supra, n. 31; Harris v. United States Mexico Oil Co. (1922) 110 Kans. 532, 204 Pac. 754. 
of the Act, this was the same as a corporation. In the words of Justice Finlayson, "the difference is in the bark, not in the pith." 37

There is no doubt but that such organizations are within the letter and spirit of the Act, and the court seemed to sum up the present California viewpoint in saying,

". . . it would be a reproach to the administration of the law if the perpetrators of such a thinly veiled attempt to circumvent the manifest purpose of this salutary legislation should go unwhipped of justice."38

Within the period of the last year there have been numerous attempts to create companies in the form of business trusts. These have been mainly for exploitation of mining and oil claims. 'The principal danger that lies in an increase of the use of this type of organization is the absence of decisions or legislation settling the liability of either trustees or purchasers. If the Commissioner is ixpected fairly to protect investors, he must know whether they are liable as partners and whether the company is to be treated as a partnership or ordinary trust in organization requirements prescribed by the Code. ${ }^{38}$ Partnership securities are clearly included within the provisions of the Act in California, ${ }^{40}$ and are specifically listed among those subject to the acts in other states. ${ }^{41}$

Some states have met this problem by a liberal construction of their constitutional provisions. In several, the word "corporations" as there used, includes ". . . . all associations and joint stock companies having any of the powers or privileges of corporations . . .", and thus these organizations in every respect are treated as corporations, even to making them meet the technical statutory requirements for corporations. ${ }^{42}$

California has such a constitutional provision ${ }^{43}$ but has adopted the better view of construing it merely as a general definition or convenient classification of organizations, the details and explana-

37 People v. McCalla, 63 Cal. App. 783, 791.

38 People v. McCalla, 63 Cal. App. 783, 792.

${ }^{39}$ In the fifth biennial report of the Corporation Department, the Commissioner recommends that some definite steps be taken along this line and condemns the business trusts as they exist today in California. He says in part, "These forms of organization usurp the functions of a corporation, to put it mildly, and undoubtedly evade the payment of their just portion of taxes."

s0 Corporate Securities Act, $\S 2$, part 3. People v. Simonsen (1923) 64

Cal. App. 97, 220 Pac. 442; Groby v. State, supra, n. 31.

11 Cowan, Manual of Securities Laws, \$ 2, part 3 of the State's Acts.

42 See T,eland S. Duxburv, Business Trusts and Blue Sky Laws, 8 Minnesota Law Review, 465, 477; Reilly v. Clyne (1925) ...... Ariz. ......, 234 Pac. 35. ${ }^{43}$ Cal. Const., Art. IV, \& 4. 
tion being in codes and acts. So, in this state, a business trust will be treated as a corporation in some respects, and not in others. ${ }^{44}$

\section{EXEMPTIONS}

The enumeration of the securities, transactions, and organizations exempted from the requirements of the Act is found principally in section 2, paragraphs 3,6 , and 9. Here are listed the standard exceptions such as bills of exchange, notes, securities sold or issued by banks, insurance companies, building and loan societies, and such crganizations regulated by some other state or federal board. In addition, it is provided that "any security listed in any standard manual of information . . .", after the Commissioner first makes a written finding that the security is adequately. listed and not in his opinion fraudulent, is excepted from the term "security" as applied in the Act. ${ }^{45}$ This gives much more freedom to the legitimate stockbroker and corporation when the standing of the security is once established. Such a provision is found in eight other states. ${ }^{48}$ A much more common provision of the same general type is that exempting securities listed upon the New York, Chicago, or other stock exchanges which the Commissioner may designate; or "any securities listed upon any organized stock exchange meeting in a city of 500,000 or over". ${ }^{47}$ It was the latter provision that played a major part in the Congressional debates upon the Dennison Bill, ${ }^{48}$ a proposed federal supplement to the state Blue-Sky laws. The successful opposition to the bill contended that this was an unfair discrimination between exchanges and between cities; was an unfair test as to the legitimacy of the securities, and was so large in the scope of its exemption as to destroy the purpose of the bill. The arguments presented another illustration of the conflict between the prevention of fraud and interference with legitimate business.

There is only one exemption that has been questioned in California, and that was declared unconstitutional by the District Court

44 Apartment Building Co. v. Daugherty (1923) 190 Cal. 521, 213 Pac. 983; Spottswood v. Morris (1906) 12 Idaho, 360, 85 Pac. 1094. But see State v. Cosgrove (1922) 36 Idaho, 278, $210 \mathrm{Pac} .393$.

\$s Corporate Securities Act, \& 2, part 6 (2).

40 Arkansas, Colorado, Kentucky, Ohio, Oregon, South Carolina, South Dakota, and Utah.

47 See Cowan, Manual of Securities Laws, p. 17.

$48 \mathrm{H}$. R. 4, 68th Congress, 1st session. It was to prevent the uses of the United States mails and other agencies of interstate commerce for the purpose of transportation or procuring the sales of securities, contrary to the laws of the states. 
of Appeal in People v. Pace. ${ }^{40}$ In section 2, part 9 of the Act, which defines "brokers", it is provided that certain classes of persons are exempted from the provisions of the paragraph, to wit,

"(a) Any owner of any security who is not the issuer or an underwriter thereof, who sells or exchanges the same for his own account; provided that such sale or exchange is not made in the course of repeated or successive transactions of like or similar character by him."

The court declared that this prevented an owner from disposing of his own property in bona fide transactions if the disposition entailed more than one sale, and as such was a deprivation of property and contrary to the Fourteenth Amendment to the Constitution of the United States. The court further upheld the defendant's contention to the effect that the words, "in the course of repeated and successive transactions" were so vague and indefinite as to make the section unconstitutional and void.

Assuming that such a holding would be affirmed by the Supreme Court and followed in other jurisdictions, it would necessarily follow that the similar provisions in 35 and possibly 38 different state BlueSky laws are unconstitutional. ${ }^{50}$ But in practically all of these states the constitutionality of the Act as a whole has been considered by Supreme Courts, and in several, the specific section, and all have been upheld as constitutional..$^{51}$ In those cases where the section in question, with identical wording with that of the California Act has been considered, and convictions affirmed under it, it has never been construed as preventing an owner from disposing of his own stock, no matter how many sales are necessary, if the transactions are bona fide. ${ }^{22}$

The Pace case concerned the president of a California corporation who personally purchased promissory notes of subscribers to stock who had defaulted, in order to help the company over difficulties. With each purchase from the company he took over the collateral stock which had been deposited with them as security.

Several other bills on the same general subject were stbmitted at the same session. H. R. 80, S. 1596, S. 1826.

19 (July 18, 1925) 47 Cal. App. Dec. 630, ... Pac.

so For instance, Arizona, Arkansas, Kentucky, and Minnesota. See Cowan, Manual of Securities Laws; Reed and Washburn, Blue Sky Law Service. ${ }^{51 G i l l e s p i e ~ v . ~ L o n g ~(1924) ~ . . . . . . . . ~ A l a . ~ . . . . . ., ~} 101$ So. 651 ; National Bank of the Republic v. Price (1925) 101 So. $651 ;$

s2 People v. Hartman (1924) 228 Mich. 171,199 N. W. 657 ; People v. Weese (1923) 225 Mich. 480, 196 N. W. 516; Dows v. Shuh (1919) 206 Mich. 133, 172 N. W. 418; National Bank of the Republic v. Price, supra, n. 51. 
His permit as a broker, and the corporation's permit were revoked. He then proceeded to dispose of this collateral stock to several different parties, and was arrested for violating the Act.

The purpose of the Act is to protect investors in stocks by requiring issuers and sellers of securities to procure a license. In no part does it pretend to regulate isolated sales or transactions as to property which individually belongs to the broker. On the contrary, each section is so worded as to limit the regulation to instances where the business of the person is to procure the investment in securities by others, and in other than single instances. However the intention was to include a person, who in order to evade the Act, purposely purchases securities in order to resell. It is this situation that the section in question was framed to prevent.

Did the section succeed in doing this? Applying the general rules that a statute should be construed with reference to the object intended to be accomplished by it, ${ }^{53}$ and in case of doubt or ambiguity, adopting that construction which is best calculated to advance its object by suppressing the mischief and securing the benefits intended, ${ }^{54}$ we should look to the aforesaid manifest purpose of the Act, and of the particular section. These considerations would indicate that the Act was not intended to cover sales made in good faith by an owner of stock. Thus it would seem that in the Pace case the court could have declared that the sales by the defendant were not in violation of the Act, and that the plaintiff failed to show a cause of action. Where the mistake was made, was in the arrest of the defendant under the Act.

As to the second ground, less stringently stressed by the court, the identical words, here declared too indefinite and vague, are found in all but a very few of the Blue-Sky laws of the different states. ${ }^{55}$ It seems that the court disregarded the primary rule that it should endeavor to construe a statute so as to give effect rather than nullify ${ }^{i t, 56}$ and lost sight of the general purpose of the Act. The only difference in the wording of the California Act and the Acts of states which the court considered in its opinion and admitted were

53 People v. Eddy (1872) 43 Cal. 331, 13 Am. Rep. 143; 36 Cyc. 1102.

54 Langenour v. French (1867) 34 Cal. 92; Coggeshall v. City of Des Moines (1908) 138 Iowa, 730, 117 N. W. 309, 128 Am. St. Rep. 221.

50 The exceptions are those states using the words, "isolated sales", as Forida and Georgia; and those states which have expressly put in the provision, "and so sold by the individual ... not for the purpose of evading the provisions of this act." Examples of the latter are Iowa, Indiana, and Maine.

58 Price v. People (1914) 238 U. S. 446, 59 L. Ed. 1400, 35 Sup. Ct. Rep. 892; Kaiser Land and Fruit Co. v. Curry (1909) $155 \mathrm{Cal} .638,103 \mathrm{PaC} .341$; Thomas v. Joplin (1910) 14 Cal. App. 662, 112 Pac. 729. 
constitutional, is the addition of the words "bona fide", or in some states, the words "isolated transaction". ${ }^{.7}$ "That the addition of "bona fide" would not clarify the meaning of the term "successive transactions" if it was ambiguous must be admitted; and "isolated transaction" in place of "successive transactions" leaves the same fundamental problem before the court, Is it, or is it not in violation of the purposes for which the Act was formulated?

The strength of the rules of statutory construction to the contrary, together with the exceedingly large number of cases where the section is found and followed, throw considerable doubt on the probability of the Supreme Court following the decision of the Pace case should the question reach that body. ${ }^{58}$

The general applicability of the California law should be emphasized. Unlike the acts in many states, the Corporate Securities Act applies to large and small corporations alike, and regardless of kind. There are no exemptions for corporations that have been organized over a certain time, ${ }^{59}$ resident companies, ${ }^{60}$ citizens of the state, ${ }^{61}$ holding companies, ${ }^{62}$ mining corporations, ${ }^{63}$ mortgage companies, ${ }^{64}$ or syndicates. ${ }^{65}$

57 The Colorado Act reads, "any security sold or offered for sale in an isolated transaction by an owner thereof..."

58 The same question was raised by the petitioner in the earlier case of In re Williams (1925) 47 Cal. App. Dec. 587, ........ Pac. ......... but the court held that as he had acted as a broker in selling property, and without a broker's permit, he was not in a position to put the point in issue on a writ of habeas corpus.

${ }_{59}$ The following states exempt issuers of securities who own a business which has been in continuous operation for over a prescribed period, and with a certain amount of profits:-Colorado, Lollisiana, Missouri, and Nebraska.

Bo States differ in exempting "local" companies, according to the way in which they meet certain stated requirements:-

a. Where part or all of property or assets are located within the state. Connecticut, Montana, and Ohio.

b. Where securities to be sold in the county of the principal place of business. Florida.

c. Where sale is for the sole account of issuer, without commission, at an expense less than that prescribed at law, and where stock issued is not for property of any kind. Indiana, Iowa, Ohio, and Pennsylvania.

d. Where storkholders do not exceed 25 in number. Massachusetts, Pennsylvania, and Wisconsin. Also see, infra, n. 61.

e. Where comnanies have a small canital stock, e.g., $\$ 25,000$. Iowa, Massachusetts, Minnesuta, Pennsylvania, and Virginia.

${ }^{81} \mathrm{Ve},-$ ont makes this a specific subdivision. New Hampshire exempts them whre they are citizens and actually doing business within the state. South Carolina exempts them in the county in which they are organized.

62 Massachusetts, Missouri, and Rhode Island exempt this class of issuer, usually providing however that the par value of the securities issued should not exceed the total par value of the securities owned and held.

${ }^{63}$ These are exempted by Idaho, Iowa, Ohio, and Washington.

64 Companies exclusively dealing in real estate mortgages are exempted by Alahama, Idaho, Kansas, Louisiana, New Mexico, Oklaloma, and Wyoming.

65 Iowa exempts this type of organization. 


\section{Penaltịes}

There are five penalties provided for breaches of the Act:

(a) Temporary suspension of the license or permit;

(b) Full revocation of the license or permit;

(c) Declaring stock issued contrary to the provisions of the permit to be void;

(d) A criminal prosecution for a misdemeanor or a felony in the case of an actual breach of the Act;

(e) Prosecution for conspiracy to violate the Act.

Recent cases and code amendments have to a considerable extent modified many of these penalties.

(a) The temporary suspension of the license of a broker or agent, or suspension of a permit to a corporation for the issuance of stock is often used where there are minor difficulties which can be arranged. A typical instance is the failure of a company to keep a sufficient amount of money or stock in escrow. The permit is usually immediately reissued upon compliance with the condition. It was the fear that the Commissioner might take advantage of this, and extend the suspension to an indefinite period against brokers that moved the court in the Abrams case ${ }^{66}$ to require a formal hearing before there could be any suspension.

(b) The revocation of permits and licenses is extremely effective, especially in the control of brokers; and finds the greatest use of all the prescribed penalties. It has even been applied in the case where a broker had sold securities in the name of a firm which he had recently left, and prior to the granting of a personal license to himself. The sale did not defraud a single vendee, but on the contrary resulted in profit to all the parties concerned. Still the court upheld the revocation of his permit subsequently issued because of the breach of the Act. ${ }^{67}$

(c) Section 12 of the Act provides that,

"Every security issued by any company, without a permit of the Commissioner authorizing the same . . ., and every security issued ... with the authorization of the Commissioner but not conforming .... to the provisions ... required by the permit of the Commissioner . . . shall be void." (Italics added.)

68 Supra, n. 5.

${ }^{62}$ Cox v. Daugherty, supra, n. 10. Also see Leaçh v. Daugherty, supra, n. 13; Eiseman v. Daugherty, supra, n. 4. 
The entire meaning of this section has not yet been settled in California, though several cases regarding it have been decided.

Under the earlier Blue-Sky law there was no such "void" clause, and the case of Winters $v$. Lindsey, ${ }^{88}$ decided after the passage of the later Act, but under the earlier law, held that due to its absence, a bone fide purchaser of stock issued contrary to the Commissioner's conditions, had no right of action against his vendor as the stocks were good.

Later cases, ${ }^{60}$ also between the vendor and vendee of stock, or involving action by the vendee to enjoin the District Attorney from prosecution, have discussed the situation, and by dicta declared that in such a case the corporation would have no action on the stock issued, and that the vendee could recover from the vendor of the void issue. In none of these cases, however, was the decision as to these points necessary.

The rule has not been extended beyond making stock issued in breach of a condition void. In a case involving contracts, ${ }^{70}$ instead of stock, it was held that the agreement entered into, beyond the limitations prescribed in the permit of the Commissioner was invalid only as between the corporation and those parties who knew of the condition in the permit; and valid as to innocent third parties. The usual type of conditions broken by contracts of the corporation are those restricting the amount of money to be expended in the sale of stock, or for advertising purposes. ${ }^{71}$

In Reno v. The American Ice Machine Company,"2 the court held that a contract between the employee plaintiff and the corporation, to take stock in return for his work was void if made prior to the granting of a permit to the company to issue stock. The ground for the decision was that section 12 of the Act made stock issued

68 (1921) 52 Cal. App. 93, 198 Pac. 43.

-o Domenigoni v. Imperial Livestock, etc. Co., supra, n. 10; Moore v. Moffatt (1922) $188 \mathrm{Cal}$ I, $204 \mathrm{Pac}$.220; Jose v. UUtley (1921) $185 \mathrm{Cal}$. 656, 199 Pac. 1037; Landwehr v. Lingenfelder (1923) ....... Mo. App. ........, 249 S. W. 723. But it has been held that a negotiable note in the hands of a bona fide purchaser for value is not subject to the defense that it was given for securities sold in violation of the act. Pitman v. Walker (1922) 187 Cal. 667,203 Pac. 739.

ro Daily Telegram v. Ocean View Oil Co. (1924) 65 Cal. App. 608, 224 Pac. 1006. In Moore v. Moffatt, supra, n. 69, the trustee in bankruptcy of a corporation brought action to recover the unpaid subscription price of stock for the benefit of creditors and the court allowed recovery on the basis of the interest of innocent third parties who relied on the contract.

71 Cases cited, supra, n. 70.

12 (April 24, 1925) 47 Cal. App. Dec. 21, Pac. Section 3 of the Act also requires a permit of the Commissioner before subscriptions for stock can be taken so that the contract was in violation of this section. 
without a permit void, and so the contract to issue the stock (the unexecuted contract in the terms of the court) is equally void.

As was illustrated above, the stocks, where issued contrary to the condition of the Commissioner are absolutely void, and the innocent purchaser has only the remedy of a law suit open to him. Georgia has a preferable view, applying the same rule to both stock issued, and contracts made in violation of the Act. ${ }^{73}$ There, the stocks or contracts, when in the hands of innocent purchasers, or affecting innocent third parties are held voidable by such parties.

The National Transportation Act, ${ }^{74}$ which gives the Interstate Commerce Commission power to supervise the issuance of securities of carriers under the Act provides that all securities issued in violation of the Act are void, and a bona fide purchaser may hold the carrier and its agents liable for damage suffered.

It seems a rather harsh rule that makes the stock bought by an innocent party void, when the only breach of the Act may be a matter which can be easily remedied if the corporation cares to do so; especially when the purchaser has no practical means of finding out as to the breach. However, it remains the California law, and the prevailing doctrine at the present time.

(d) The meaning of the last few lines of section 14 of the Corporate Securities Act has been of material concern recently. For a violation of the Act, the guilty party

"shall be punished by imprisonment in the state prison not exceeding five years, or in a county jail not exceeding two years . . or by fine ... or by fine and imprisonment."

It is thus evident that the breach may be either a felony or a misdemeanor.

But what if prosecution for a misdemeanor is barred by the statute of limitations? Then the court has no longer the choice of punishments given it by the legislature, but is forced to punish the party for a felony, or not at all. The jury may have already brought in a verdict of "guilty" against the defendant, so that all there is left for the court to do is to punish for a felony. Then, according to the argument of the plaintiff in the case of Doble v. Superior Court, ${ }^{75}$

${ }^{73}$ Laws, 1920, No. 754. Virginia takes an intermediate stand as to contracts. See Walters \& Martin v. Homes Corp. (1923) 136 Va. 114, $116 \mathrm{~S}$. E. 366. Arkansas goes so far as to make it unlawful for newspapers to publish advertisements of securities not exempted or not approved by the Commissioner. Acts, 1915, No. 242, 1917, No. 214, \& 13.

7441 U. S. Stats. at L. 456 , U. S. Comp. Stats. (1923 Supp.) $\$ 100711 / 4$, Fed. Stats. Ann. (2d ed., 1920 Supp.) 72. See 27 A. L. R. 1169.

75 (Feb. 9, 1925) 46 Cal. App. Dec. 434, Pac. 
the court is deprived of the choice given it by the Act, and as there is no choice, there is no punishment; and as punishment is one of the essential elements to constitute a crime, the plaintiff must be dismissed entirely. The District Court of Appeal has held otherwise, and declared that there is a designation of a punishment in section 14, and that the fact that it is alternative is no bar to the court to convict for a felony, even though it cannot for a misdemeanor in that instance.

That the legislature intended some punishment is not questioned, but there being such a difference in the degree of violations of the Act, it seems wrong to say that a party implicated only to the slightest extent, and ordinarily punishable only for a misdemeanor, should be made to stand the additional punishment for a felony because the state was lax in its prosecution, allowing the statute to bar the prosecution for the misdemeanor. If we follow the Appellate Court we must say this or pin our faith on a jury acquitting the minor offender.

Where there has been an actual conviction for a felony before the statute has run, the election is made, and though the case is appealed, the court may treat the defendant as a person convicted for any other felony; the fact that there was an original election between a misdemeanor and a felony making no difference. ${ }^{70}$

Another interesting question arose over the prosecution for statements made in the application for a license. In People v. Boggess, ${ }^{77}$ the defendant was prosecuted under section 14 of the Act for including false statements as to earnings of the corporation in his application for a permit to issue securities. This information was entirely surplus matter and was not required by the provisions of section 3 . Notwithstanding this fact, the court found this to be a "filing, with knowledge of its falsity, a representation concerning the company", and upheld a conviction of the defendant for a breach of the Act.

Criminal prosecutions for violations of the Act are on the increase in California, and are the only effective means for the elimination of certain types of offenders. Certain organizations of the type of the "Better Business Bureaus" have been a great aid to the Corporation Department in reporting violations, and in the investigation of security issues. They succeed in gaining the confidence of many

76 Frankfort v. Superior Court (1925) 46 Cal. App. Dec. 542, ...... Pac. .......

77 (1924) 194 Cal. 212, 228 Pac. 448. But see Davis v. State (1897) 51 Neb. 301,70 N. W. 984 , an almost identical situation except that a punishment was provided in another part of the Act. 
persons who otherwise would not have their investments looked into until some fraud had been committed and the situation was beyond remedy.

(e) Up to the 1925 session of the legislature it looked as though California had a good-sized loop-hole in the penal provisions of its Corporate Securities Act. By the technical wording of the Penal Code there was no such crime as a conspiracy to violate the Corporate Securities Act. Section 182 of the Penal Code provides for conspiracies to commit a felony and makes them punishable in the same manner and to the same extent as prescribed in the Penal Code for the punishment of said felony. But there is no punishment for a breach of the Corporate Securities Act found in the Penal Code, but solely in the Act itself. Then, as there was no punishment for a conspiracy provided for in the Act, and there is no crime without a punishment, ${ }^{78}$ there could be no such crime as a conspiracy to violate the Corporate Securities Act. The question was raised, and so decided by the District Court of Appeal in Doble v. Superior Court. ${ }^{70}$

The 1925 legislature filled in this gap ${ }^{80}$ by simply adding the words,

". . . or who with one or more other persons, conspires to violate any permit or order issued by the Commissioner, or any provisions of this Act"

to section 14 of the Act, and provided a penalty therefor. The result will be that a large class of dangerous offenders will not hereafter be able to plan their fraudulent deeds with impunity.

These five represent a formidable list of penalties, but there is still more in the line of penalties that may be done in this state. When we look at the results of the last legislature we begin to feel that California favors the placing of all the teeth possible in its Corporate Securities Act. The material increase in the appropriation plus amendments to eleven sections of the Act justify our anticipation of an increased strictness in its enforcement.

The granting of power to the Commissioner to bring an action

78 Penal Code, §15; 16 C. J. 68; Ex parte Ellsworth (1913) 165 Cal. 677, 133 Pac. 272; People v. McNulty (1892) 93 Cal. 427, 26 Pac. 597, 29 Pac. 61; People v. Lunn (1913) 81 Misc. 476, 143 N. Y. Supp. 401.

${ }_{78}$ Supra, n. 75. In People v. Eiseman (1924) 45 Cal. App. Dec. 358,

Pac. ....... the indictment included a count for conspiracy to violate the Act but the court did not consider the point. The indictment also charged such a conspiracy in People v. Barnard (1923) $63 \mathrm{Cal}$. App. 562, 219 Pac. 756, but as it was defective for other reasons this question was not settled.

80 Cal. Stats. 1925, ch. $447, \S 9$. 
to enjoin the sale or further issue of securities in case an investigation is necessary, ${ }^{81}$ and power to have a receiver appointed for the business if a fraud is discovered, ${ }^{82}$ are forward steps that California might well take to insure a maximum protection to the investor and creditor. Many states have adopted the plan of providing a separate prosecutor for the Corporation Department, ${ }^{83}$ another move toward a better enforcement of the Acts.

\section{Additional Amendments. The Results of the Act.}

The 1925 amendments are the culmination of a long campaign by the combined forces of corporation lawyers, investment bankers, and the Corporation Department, as few changes had been made since the present Act superseded the Investment Companies Act in 1917.

The addition of the crime of conspiracy to violate the Act, and several other important changes have already been considered. The other alterations are merely to clarify, and to make sure the inclusion of certain types of securities. Section 2, parts 8 and 10, now both specifically include any instrument representing a right to share in any of the income or earnings of a business, with the exception of leases not offered to the public. This will assure the Commissioner of authority to regulate the issue of many "interests" of the so-called business trusts.

The definition of the word "fraud" has been changed so as to include constructive as well as actual fraud, wherever used in the Act. ${ }^{84}$

Section 25, which permits a California corporation to take subscriptions to stock prior to incorporation, has had a material proviso added, which withholds the right to collect any portion of the consideration for these subscriptions until a permit is issued for this purpose.

There is no act, whether it be of the "all-inclusive" type of California, or like the Fraud Acts of New York and Maryland, ${ }^{85}$ that will make the public impregnable against fraudulent practices of

81 Maine Laws, 1923, ch. 144, § 135; N. Y. Laws, 1925, ch. 239, § 2.

82 N. Y. Laws, 1925, ch. 239, \& 3.

8a This will relieve the deputies of the Attorney-General's office of this duty, many of whom are connected with corporations.

is Cal. Stats, 1925, ch. 447, \&1 (12).

85 These acts permit the Attorney-General to make investigations and to order persons selling securities to desist where a fraud is being committed.

See 24 Columbia Law Review, 79 for the distinction between the types of acts, and the relative strength of each. 
brokers and agents. ${ }^{86}$ The Corporate Securities Act has accomplished a great deal in the seven years of its existence; and there has been a steady endeavor upon the part of the Corporation Department to reduce the time and expense which it added to the process of incorporation. To a company which has a large bond issue to market, with interest alone amounting to thousands of dollars a day, the number of days of waiting for a permit of the Department is exceedingly important. Then the additional fees which the Act has occasioned cut quite a figure in many cases. It is significant to note in this regard that up to 1925, this supposedly only "self-supporting" department is credited with a surplus of $\$ 666,000$ over all expenses. ${ }^{87}$

For the average company, however, the permit is issued very quickly and the fees are small, so the requirements of the Act justify little criticism. As to the others, the material increase in the number of the staff ${ }^{88}$ in the last year will help a great deal toward cutting down the time, and thus the expense entailed in acquiring the needed permit.

Lionel B. Benas.

Oakland, California

86 At the present time there seems to be a wave of giant "merger" frauds through the Western part of the United States. Some of California's most prominent business men have lost large sums of money through contributions to secret plans to merge five of the large railroads, or in another case, seven well known oil companies. Another plan to merge several automobile concerns is under investigation at the present time.

Another problem that the Commissioner faces is to emphasize to the public that the Corporation Department is not an insurer of success in business, and that due care must be used in investing notwithstanding that the company has been granted a permit.

${ }^{87}$ Fifth Biennial Report of the State Corporation Department, p. 3.

88 Due to the increased appropriation the number of employees has been changed as follows: investigators, from two to ten; auditors, from five to thirty-five; deputies, from seventeen to twenty-seven. 